\title{
Lumen
}

Selected Proceedings from the Canadian Society for Eighteenth-Century Studies

\section{'That Devil Curiosity Which Too Much Haunts the Minds of Women': Eliza Haywood's Female Spectators}

\section{Juliette Merritt}

Volume 16, 1997

Freedom and Boundaries

Émancipation et frontières

URI : https://id.erudit.org/iderudit/1012445ar

DOI : https://doi.org/10.7202/1012445ar

Aller au sommaire du numéro

Éditeur(s)

Canadian Society for Eighteenth-Century Studies / Société canadienne d'étude du dix-huitième siècle

ISSN

1209-3696 (imprimé)

1927-8284 (numérique)

Découvrir la revue

Citer cet article

Merritt, J. (1997). 'That Devil Curiosity Which Too Much Haunts the Minds of Women': Eliza Haywood's Female Spectators. Lumen, 16, 131-146.

https://doi.org/10.7202/1012445ar 


\section{0. 'That Devil Curiosity Which Too Much Haunts the Minds of Women': Eliza Haywood's Female Spectators}

The quotation in this title, from Eliza Haywood's first novel Love in Excess: or, The Fatal Enquiry (1719-20), implies that curiosity is a transgressive impulse by which women, in particular, are bedeviled. Behind this belief lie Eve and Pandora, women who possess an irresistible and fatal hunger for knowledge, and who provide the models for an improper and dangerous desire to know. While Samuel Johnson considered curiosity to be 'one of the permanent and certain characteristicks of a vigorous intellect,'(184) he also regarded it with an ambivalence typical of his time. ${ }^{1}$ Curiosity is regarded with suspicion, first, because of its link with prurience - the sexual curiosity of the voyeur and the prying curiosity of the spy are understandably met with distaste and distrust. Second, the desire to know can too easily exceed the proper limits of human knowledge. ${ }^{2}$

In its visual aspect, curiosity is of particular importance to European culture in the eighteenth century, a period which foregrounded many aspects of vision, including the physiological, epistemological, social, and sexual. In No. 46 of The Spectator (1711), a letter is published from an 'Ogling-Master' wishing to show the Spectator his manuscript, The Compleat Ogler, wherein he claims to have perfected the 'whole Art of Ogling' including the 'Church-Ogle' and the 'Play-house Ogle' (199). Reference to an 'Art of Ogling,' however ironic, reflects the eighteenthcentury preoccupation with seeing and being seen; for Foucault, 'the foreign spectator in an unknown country, and the man born blind restored to light' were the two myths underlying eighteenth-century philosophy (65). Virginia Swain links this increased interest in spectatorship with the appearance of new visual technologies such as the microscope and telescope, discoveries which brought 'a new emphasis on the spectator/observer' (6). Marjorie Nicolson has written extensively on the influence of optical advances on literature. In 'The Microscope and English Imagination' she documents how the work done by the Royal Society to promote the microscope spread throughout popular culture. ${ }^{3}$ 
Nicolson pays particular attention to the popularization of the microscope amongst women, which, she states, 'may be dated from [the] visit of the Duchess of Newcastle to the Royal Society on May 30,1667' (37). ${ }^{4}$

Literary texts quickly exploited the discursive and narrative possibilities of the increased significance of the 'spectator/observer.' For example, a discursive role for the curious spectator is quite consciously created in Addison and Steele's Spectator. Believing curiosity to be 'one of the strongest and most lasting Appetites implanted in us,' the Spectator admits that it has been his 'prevailing Passion' and the 'sole Entertainment' of his life (111). Conscious of the epistemological advantages of his position as a silent 'Looker-on,' the Spectator establishes his discursive authority within a visual economy where the one who sees is the one who knows. Thus he acquires a knowledge of life which is comprehensive and theoretical, and he 'can discern the Errors in the Oeconomy, Business and Diversion of others, better than those who are engaged in them; as Standers-by discover Blots, which are apt to escape those who are in the Game' (5). Participation in the 'Game' of life impairs perception. The Spectator's detachment creates a 'knowing Eye' which allows him to hold out a promise of enlightenment to his readers. He emphasizes his marginality:

He who comes into Assemblies only to gratify his Curiosity, and not to make a Figure, enjoys the Pleasure of Retirement in a more exquisite Degree, than he possibly could in his Closet: I can very justly say with the antient Sage, I am never less alone than when alone. . I am insignificant to the company in publick Places. (19)

So insignificant is he that although his person is well known, he is routinely referred to as 'Mr. what-d'ye-call-him' (19). A voyeur rather than an exhibitionist, the Spectator acquires the full benefits of unobstructed looking. To convince us of his remarkable scopic abilities, the Spectator repeats a familiar theory: the loss or suppression of one sense produces heightened capability in another. The consequence of his voluntary 'Resignation of Speech' is 'a more than ordinary Penetration in Seeing.' The Spectator's claim to have access to the 'inmost Thoughts and Reflections' (20) which are concealed from the ordinary observing subject is based on the traditional links between vision, penetration, and truth, the eye being the primary instrument of discovery and revelation. As an autonomous 'subject placed at the centre of a world' (Bryson 87), the Spectator adopts the Cartesian position where he believes all is open to his unchallenged gaze, and assumes an unproblematic relationship between seeing and knowing. 
The masculine nature of this 'Penetration in Seeing' is obvious; the phallic metaphor affirms it and the Spectator believes women have less 'Penetration' because they are easily distracted by whatever is 'showy and superficial.' He knows, for example, of a young lady, 'warmly sollicited by a Couple of importunate Rivals' who was finally won when 'one of the young Lovers very luckily bethought himself of adding a supernumerary Lace to his Liveries' (66-67). While women's lack of discernment may be blamed on a faulty education that has made them shallow, capable only of considering the 'Drapery of the Species' and not the more important 'Ornaments of the Mind,' the Spectator's dim view of women's faculty of 'Penetration' reflects at a deeper level the conventional split between masculine subject and feminine object. Relations of power, traditionally conducted through this gendered division, give to men the power and privilege which accrues to the subject position; hence, the Spectator's belief in his superior 'Penetration in Seeing' is as much a function of his sex as his silence.

The inevitability of this gendered division is currently undergoing critical analysis by feminist theorists of the gaze, some of whom question whether 'the gaze is always male' (Gamman 5). Others, including Ann Kaplan in Women and Film, claim that the 'gaze is not necessarily male (literally), but to own and activate the gaze ... is to be in the 'masculine' position' (30). At the heart of this debate are concerns regarding the possibilities for female subjectivity and agency within a specular economy which, at the very least, privileges male looking. ${ }^{5}$ Theoretical work on the gaze comes primarily from feminist film criticism, but feminist literary critics have found the critique of the complex workings of the gaze useful in textual and cultural analysis. ${ }^{6}$

The question under investigation here is, what might a female gaze look like? Haywood was not of a single mind on this issue. In The Female Spectator and The Invisible Spy, she shows that the critical gaze of the spectator is available to the female author. ${ }^{7}$ For example, the persona she creates in her periodical The Female Spectator exchanges her former position as an object - a coquette who seeks opportunities for 'shewing' herself - for that of subject when she becomes a spectator in her new role as writer and educator. Such an appropriation of masculine privilege is not without risks, however. Its accomplishment is dangerous and uncertain for a character such as Alovisa in Love in Excess, whose tragic end emphasizes the difficulty inherent in any woman's attempt to make the transition from object to subject. By comparing these two treatments, we can consider how Haywood understood the problems, risks, and rewards of female spectatorship.

Taking Mr. Spectator, her 'learned brother of ever precious memory,' as her model, the Female Spectator attempts to partake of the discursive 
authority the position of observer entails. Yet, for women writers, a straightforward appropriation is not possible. Haywood requires a rhetorical gesture through which she can justify this appropriation and establish her worthiness for the role. Rightly eschewing the eccentricity and irony of her male counterpart as unsuitable, she creates her persona out of an easily recognized (and much-criticized) female type - the reformed coquette. As a coquette, the Female Spectator had deliberately inserted herself into the specular field, seeking opportunities to 'shew' herself. Ingeniously, her experience as an object, a position assumed to have epistemological limits, now forms the basis for her knowledge and authority. In her new guise as a mature, sober, and reflective woman, her earlier worldly experience serves as an argument for her suitability as an educator:

The company I kept was not, indeed, always so well chosen as it ought to have been, for the sake of my own interest or reputation; but then it was general, and by Consequence furnished me, not only with the knowledge of many occurrences, which otherwise I had been ignorant of; but also enabled me, when the too great vivacity of my nature became tempered with reflection, to see into the secret springs which gave rise to the actions I had either heard, or been Witness of. (2)

The Female Spectator promises to uncover the mysteries of human motivation through her capacity for reflection, judgment, and discernment, all features of a rational intelligence. What she has learned regarding the human heart, the 'secret springs' she speaks of (traditional epistemological territory for women), is the announced subject of her writing. ${ }^{8}$ This clever rehabilitation of the coquette not only gives her female readers a social and specular position with which to identify, but also demonstrates the possibility of transcending the subject/object structure once a woman exchanges the desire to be seen for the desire to see.

The Female Spectator's scopic abilities are one aspect of her bid for discursive authority. She also wants to be 'as universally read as possible' and so must find common ground upon which to appeal to a broad readership. Like Addison and Steele's Spectator, she

found that curiosity had, more or less a share in every breast; and my business, therefore, was to hit this reigning humour in such a manner, as that the gratification it should receive from being made acquainted with other people's affairs, might at the same time teach every one to regulate their own. (3) 
Haywood uses curiosity for a rather ambitious discursive purpose - to reach and unite a large and diverse audience. It is only vaguely suggested that the Female Spectator's eyes will be where they don't belong - spying on 'other People's Affairs' - and the more dubious aspects of spectatorship, such as voyeurism, are de-emphasized. She does, however, alert her reader to the network of spies which will bring back intelligence to the Female Spectator; together they will become the 'eyes' for a female readership. Curiosity is not (at least not forthrightly) a source of personal pleasure for the Female Spectator, as it is for her 'learned brother. ${ }^{\prime}$ Haywood avoids any explicit appeal to the pleasures of voyeurism; instead, curiosity, it is argued, is a route to self-regulation.

In employing curiosity for her own discursive ends, the Female Spectator makes no gender distinctions; the reader assumes that as a universal appetite, curiosity resides equally with men and women. In her ability to see into the 'secret springs' of human behaviour, she also challenges Mr. Spectator's belief that women have no 'penetration.' Furthermore, she makes the transition from object to subject/author appear easy; she simply writes herself into existence. In an act of selfcreation, she evolves from one who was once an object of the look to one who has acquired a critical eye. For the heroines of Haywood's fiction, however, such a move is more difficult, and in the case of Alovisa of Love in Excess, who also attempts to make this transition from object to subject, the process is deemed both improper and dangerous. Her 'fatal Enquiry' into her husband's infidelity, born of her 'impertinent Curiosity,' is a threat to his freedom and authority. When she puts a 'diligent Watch' on all his actions and seeks an 'ocular Demonstration' of his adultery, she subversively defies the constraints of her place as an object. Her transgressive curiosity is a bid for subjectivity and the access to the knowledge it provides.

Such a description of Alovisa is consistent with the focus of my discussion so far - the role and privileges of the observer in specular relations - but it is somewhat misleading. Alovisa is more accurately depicted as one in whom two positions, spectacle and spectator, are united: her need to be seen is equal to her desire to see. Love in Excess begins with Alovisa's attempt to direct the gaze of Count D'Elmont precisely because he does not see her as she wishes to be seen. He is, apparently, 'not an Object to be safely gaz'd at' (56), and Alovisa, like most of the novel's female characters, falls in love at the first sight of him. In Haywood, sight is a vehicle for female sexual passion, and male characters are created to be the charismatic objects of women's desire. Alovisa is piqued that D'Elmont addresses her without any 'Mark of a distinguishing Affection.' 'Wherefore,' she asks, 'has the agreeing World join'd with my deceitful Glass to flatter me into a vain Belief I had 
invincible Attractions? D'Elmont sees 'em not; D'Elmont is insensible!' (2) To be desired, one must first be seen. Modesty dictates that Alovisa must await D'Elmont's notice, and she, like all other women who gaze lovingly upon him, 'curs'd that Custom which forbids Women to make a Declaration of their Thoughts' (2). To correct D'Elmont's insensibility by directing his vision, she writes to him anonymously, encouraging him to find the 'little God' where he 'would most desire to find him.' Certain of D'Elmont's 'Penetration,' Alovisa expects that he will discover her as the correct object of his search, unless his desiring gaze has already been fixed 'by a former Inclination' (4).

Alovisa also intends to use a specular language, what Steele calls the 'Language of Looks and Glances,' to direct D'Elmont's gaze. As she dresses for the ball they are both to attend, she also 'dresses' her eyes:

[S]he consulted her Glass after what Manner she should dress her Eyes; the gay, the languishing, the sedate, the commanding, the beseeching Air, were put on a thousand times, and as often rejected. (5)

To Alovisa, her deportment, including an appropriate 'look' in her eyes, is as much a part of her toilette as her clothes and jewels. She is preparing to stage herself, to speak a language of the eyes which she hopes will draw D'Elmont's look. Although willing to manipulate this visual system, she operates on the object side of the look and so behaves in ways appropriate to her sex; as an object she has the manoeuvring room granted to women - she can fashion and ornament herself in preparation to be seen.

D'Elmont's powers of discernment, however, cannot be relied upon. Alovisa, 'arm'd with all her Lightnings,' anxiously awaits D'Elmont's entrance with 'her Eyes fixed towards the door' (6). But to her dismay and shock, he enters with Amena, and Alovisa 'saw, or fancy'd she saw, an unusual Joy in her Eyes, and dying Love in his' (6). Moments before, helping Amena from her coach, D'Elmont had noticed her trembling hand and a 'Languishment in her Eyes' (7). Immediately he assumes her to be the anonymous writer. Although correctly discerning Amena's desire, D'Elmont misdirects his gaze and fixes upon the first woman he sees. Amena has unknowingly intercepted the Count before Alovisa can communicate, through her eyes, her desire.

Although an unlucky accident robs Alovisa of the opportunity for which she has so carefully prepared, her body still expresses her response to this unfortunate turn of events. When she sees that D'Elmont has missed the mark, she is completely discomposed; falling into a swoon, she must be taken home. Alovisa's disorder is not that 'sweet confusion' requisite in the modest heroine. The loss of her composure, a 
spectacle of which she is ashamed, is produced by an excess of various emotions: 'Disdain, Despair, and Jealousy at once crowded into her Heart, and swell'd hers almost to bursting' (6). Later, when D'Elmont learns that Alovisa is the anonymous writer, he will remember her swoon and interpret it correctly as a forceful expression of frustrated passion. But for now, he is as mystified by Alovisa's collapse as everyone else.

Undeterred by this setback, Alovisa again writes to 'direct [D'Elmont's] erring Search' (8), now appealing to his ambition: 'Heav'n ... . design'd you not for vulgar Conquests,' she writes, 'aim at a more exalted Flight, and you will find it no Difficulty to discover who she is that languishes' (11). D'Elmont's 'penetration' is as faulty as ever - only by chance does he finally discover the author of the letters. When he does so they finally marry, but Haywood shows that visual signification is a complex and unpredictable social system impossible to dominate. Alovisa's attempt to impress her will upon it must inevitably fail because in Haywood's discourse of desire, genuine passion is spontaneous and cannot be bound by such self-conscious, deliberate efforts to master the specular dynamics that serve it. However, if D'Elmont and Alovisa cannot connect through the loving gaze, they can through D'Elmont's ambition. The one 'invincible Attraction' Alovisa possesses - her money - accomplishes all.

That Alovisa chooses her husband and exercises whatever means necessary to secure him is a consequence of her autonomy. Rich and, with both parents dead, independent, she possesses more freedom than is usually granted to women. Yet Alovisa finds that such advantages are to no avail in dealing with her husband's infidelity. She has no power to hold D'Elmont's desire, and her happiness ends abruptly when D'Elmont first gazes upon Melliora, his new ward and the true object of his desire. 'Quicksighted' enough to discern immediately the alteration in her husband's behaviour, Alovisa goes to him in his closet. Finding the door locked,

her Curiosity made her look thro' the Key-hole, and she saw him sometimes very earnestly reading a Letter, and sometimes writing, as tho' it were an Answer to it. (66)

At the moment that Alovisa puts her eye to the keyhole she becomes a threat to her husband's autonomy and security. She penetrates into his private space and acquires the covert power of the spy. Bribing his servant to obtain the letter, she discovers his dissatisfaction with his marriage but not the cause. Accordingly, she intends to put a 'diligent Watch' on all his 'Words and Actions' (69). Alovisa's curiosity will be a 
driving force in the narrative; indeed, her search into the identity of D'Elmont's beloved is the 'fatal Enquiry' of the title. Her desire to see, characterized by 'that Devil Curiosity which too much haunts the Minds of Women,' (141) is portrayed by the novel as a transgressive feminine attribute. Angry at his wife's 'impertinent Curioisty' when he discovers she has tampered with his correspondence, the Count is indignant because Alovisa's spying undermines both his privacy and his assumption that marriage need not interfere with his sexual career.

When Alovisa discovers that her husband loves another she is racked by feelings of jealousy, rage, and abandonment. 'I know he hates me,' she laments, 'I read it in his Eyes, and feel it on his Lips; all Day he shuns my Converse, and at Night, colder than Ice, receives my warm Embraces' (107). Indeed, D'Elmont now regards his wife as his 'ill-Genius' and the 'Bar' between him and Melliora. Motivated by a desire for revenge, Alovisa becomes obsessed with discovering the identity of the woman who has replaced her, but like her foiled attempts at directing D'Elmont's 'erring Search,' her own search is repeatedly frustrated and misdirected. Curiosity may be Alovisa'a presiding spirit but she is motivated primarily by the need to exert some influence over her destiny. Unable to accept passively the loss of D'Elmont's affection and submit to his authority, exposure of the 'curst Adultress' will give her the power to create a public scandal. To accept her fate as a rejected wife is, for her, a kind of enslavement. The alternative is, once again, to enter the visual field. When Baron D'Espernay, who possesses the secret Alovisa covets, promises an 'ocular Demonstration' of the adulterous couple in return for sexual favours, Alovisa is ecstatic, believing she will gain the certainty of visual verification. The Baron assures her, 'Madam ... you shall have greater Proofs than Words can give - ocular Demonstration shall strike Denial dumb' (117). Given Alovisa's preoccupation with seeing and being seen, it is not surprising that she is enticed by the prospect of being an eyewitness.

This 'ocular Demonstration' is to come from a plot laid by D'Elmont and the Baron to rape Melliora, euphemistically conceived as a 'Sacrifice to Love.' However, D'Espernay's sister Melantha, also enamoured of the Count and a more willing sacrifice, discovers the plan and places herself in Melliora's bed to await the Count. Alovisa is to break in upon the lovers, but the bed trick foils both her and D'Elmont's purposes. In the darkened room Melantha secretly receives the Count, and hides beneath the covers when Alovisa bursts upon the scene. In a rage she tries to strip away the bedclothes but is prevented by D'Elmont. He attempts to 'stop her mouth ... [but] cannot prevent her from shrieking out Murder! Help! or the barbarous Man will kill me!' (126). Alovisa's words, and the situation of frustrated vision, will turn out to be prophetic. 
Governed as she is by curiosity's 'appetite,' Alovisa appears to occupy the masculine position of the one who sees. Yet she cannot achieve the 'Penetration in Seeing' she is after. 'Ocular Demonstration' is proven unreliable and its promise of certain knowledge remains unfulfilled. This is not only due to Melantha's firm grip on the bedclothes; even if she had been uncovered, the knowledge Alovisa seeks would still elude her. The privileges of spectatorship are not within Alovisa's grasp, perhaps because she never truly escapes her position on the object side of the look. In trading on her desirability, she compromises her autonomy and very nearly becomes completely dominated by D'Espernay. But more significantly, Alovisa's frustrated efforts are due to her own commitment to spectacle. She wants, apparently, to be a witness, and responds breathlessly to D'Esparnay's proposal, yet in the crucial witnessing scene Alovisa almost immediately transforms herself from hopeful spectator to discomposed spectacle. As in her earlier response to D'Elmont's entrance with Amena, Alovisa's prostrate and hysterical body becomes the centre of attention: 'the violence of so many contrary Passions warring in her Breat at once, had thrown her into a Swoon, and she fell back ... motionless, and, in all Appearance, dead' (126-27). Indeed, in terms of the visual focus of this scene, what we see is not D'Elmont and his mistress caught in flagrante, but the spectacle of Alovisa overcome by her rage and disappointment. D'Elmont, who now looks upon her 'with Rage and Hate, for that jealous Curiosity which he suppos'd had led her to watch his Actions that Night,' believes his wife to be in possession of the look, and that he has caught her watching. But this is not accurate; Alovisa's capacity to see is repeatedly undermined in the novel by her inability or unwillingness to transcend her propensity to specularize herself.

Her failure to become an effective eyewitness prompts a change in strategy in which she does not even attempt to be a spectator. Negotiating yet again with the Baron, she agrees to a meeting where, in return for the coveted name, she will fulfill her bargain. However, she has planned against this eventuality by secretly placing D'Elmont's brother, Chevalier Brillian, in a closet. In the position of spy, he now owns the gaze and deploys it to greater effect. Once Alovisa has the name, he is to rush out and defend her honour. Alovisa now occupies a thoroughly feminine role. The plan is partly successful; the Baron is challenged and killed by Brillian, saving Alovisa from her agreement. However, her enquiry suddenly becomes fatal to herself as well. Coming to 'alarm the Family,' Alovisa runs accidently upon D'Elmont's sword in the darkened gallery, In a rather macabre and ironic collapsing of the spectator/spectacle structure, here Alovisa neither sees nor is seen. However, when D'Elmont calls for lights to illuminate the scene, we witness, yet 
again, Alovisa's specularized body, a 'dreadful View,' impaled upon her husband's sword. Each time Alovisa attempts to see, her position as object in the field of vision is reaffirmed.

It seems that the Count inadvertantly silences Alovisa, yet her death resonates symbolically; she is killed by her husband's sword, the symbol of his phallic power, a power invested in him by his sex and his aristocratic status. The manner of Alovisa's death suggests that a woman's 'impertinent Curiosity' is not only improper, but punishable as well.

Although we can sympathize with Alovisa's sense of injustice and betrayal, Haywood's treatment of her is ambivalent. Demonized in the novel, she is seduced by 'that Devil Curiosity' and occupies the dubious position of spy and voyeur. To D'Elmont, she becomes an 'ill-Genius,' a kind of evil presiding spirit. In an ironic comment on her own bid for 'Penetration in seeing,' she is stabbed in the dark. This may be, perhaps, a metaphor for her own darkness; while her desire for revenge is understandable, it is an ignoble objective, and Alovisa, like many of the novel's characters, does not see beyond her own self-interest. Yet Alovisa's story is a tragic one, and she, more than any other, is the novel's 'Sacrifice to Love.' It is typical of Haywood to condemn intemperate and immoderate emotions, especially the twin passions of rage and jealousy. Nonetheless, the sincerity and degree of Alovisa's suffering guarantees that she has a claim on the reader's sympathy. As David Oakleaf states, in Haywood 'all lovers, and only lovers, are subjects. That is why Haywood's narrator promiscuously confers her narrative favours on all of them' (16).$^{10}$ Yet Alovisa is not content to be a rejected and suffering lover. She wants knowledge and power.

Whether Alovisa actually learns the name she seeks is not revealed; silenced by D'Elmont's sword, 'Alovisa spoke no more' (145). For her, the crucial links between spectatorship, knowledge, and agency never come together. Alovisa's death not only facilitates the novel's plot - to bring about the marriage of $\mathrm{D}^{\prime}$ Elmont and Melliora - it also points to questions regarding appropriate and successful ways for women to exercise power. Contrary to Alovisa's trangressive compulsion to see, the Female Spectator acquires the privilege of sight in an act of selfauthorization which establishes her credibility as an educator. Alovisa's failure to achieve the position of 'Looker-on' can be ascribed, in part, to her inability to conceal her specular activities, as her desire to be an overt witness to the sexual scene of $D^{\prime}$ Elmont and his mistress demonstrates.

The Female Spectator's anonymity, on the other hand, brings her a certain mastery, a manoeuvre Haywood exploits more fully in The Invisible Spy. Published in 1755, this is yet another example of how Haywood uses the figure of the spectator/spy to acquire a position from which to enter public discourse. ${ }^{11}$ The Invisible Spy draws upon the 
popular interest in the Oriental tale. In return for a good deed, a friend 'descended from the ancient Magi of the Chaldeans' rewards the author with any selection from a 'Cabinet of Curiosities' (2-4). Unable to choose between the 'Belt of Invisibility' which 'fasten'd round the body, next the skin, no sooner becomes warm than it renders the party invisible to all human eyes,' and the 'Wonderful Tablet' which 'in whatever Place it is spread open, receives the Impression of every Word that is spoken, in as distinct a manner as if engrav'd,' (10) the author explains the equal appeal of the two objects:

I was very much divided between these two; - the Belt of Invisibility put a thousand rambles into my head, which promised discoveries highly flattering to the inquisitiveness of my humour; but then the Tablet, recording every thing I should hear spoken, which I confess my memory is too defective to retain, fill'd me with the most ardent desire of becoming master of so inestimable a treasure: - in fine, - I wanted both; - so encroaching is the temper of mankind, that the grant of one favour generally paves the way for solliciting a second. (11-12)

Happily, the friend offers both: 'Nor do I wonder you should desire to unite them; - they are, in a manner, concomitant; and the satisfaction that either of them would be able to procure, would be incompleat without the assistance of the other' (13). Here, in the concomitancy of Belt and Tablet, the discursive potential of the connection between spectatorship and writing is made explicit. A privileged vantage point is created from which the author (whose sex is deliberately concealed) ${ }^{12}$ can employ the critical gaze of the spectator. This authorial positioning, invisible and on the margins, is currently regarded as a primary site of female discourse. The Invisible Spy, who can see without being seen, and has no fear of having his/her gaze met and challenged, understands its power ${ }^{13}$ The androgyny of the Invisible Spy is made possible by his/her invisibility.

More often, however, distinctions are made between masculine and feminine forms of power. Such a distinction is made in Steele's Spectator 53. A 'reformed Starer' writes to complain of the power of a female 'Peeper' who, despite his best efforts to keep his 'Eyes from wandring,' is 'resolved to bring down [his] Looks, and fix [his] Devotion on her self.' Attempting to look away, he is 'detained by the Fascination of the Peeper's Eyes, who had long practised a Skill in them, to recal the parting Glances of her Beholders.' Certain that the Spectator 'will think a Peeper as much more pernicious than a Starer, as an Ambuscade is more to be feared than an open Assault,' (227-28) he makes a case for the considerable scopic power of the 'Peeper.' The 'ambuscade,' covert and indirect, is the normative means of feminine power. ${ }^{14}$ In this gendered optical 
struggle between 'Starer' and 'Peeper,' female power remains within a sexual economy where women exploit their position as desirable objects to control the male look. As a model for female power, the 'Peeper' represents a traditional perspective. Drawing on Dante's two categories of $\sin$ in the Inferno, violence (forza) and fraud (froda), Northrop Frye discusses this traditional gendered division in the exercise of power. ${ }^{15}$ While men may use either violence or fraud to achieve their objectives, 'the physical weakness of woman makes craft and guile her chief weapons' (6-18). Women must veil their gaze for its effects to be felt - they are in greater need of strategy.

Alovisa is not without strategy, but the anonymity demanded by custom renders her invisible precisely when she needs to be seen by D'Elmont, and when she wishes to be an eyewitness, she fails to conceal the attempt and so loses power. Her curiosity is regarded as sinister, associated with the original transgression of Eve, ${ }^{16}$ and she is punished for it. The Female Spectator, however, successfully valorizes curiosity; if she does not purge it entirely of its dubious aspects, she certainly manages to divert our attention away from them. Her personal reformation provides a basis for her discursive authority, and her anonymity gives her the marginal position enjoyed by Mr. Spectator. The Invisible Spy is an even more forthright, unapologetic appropriation of the position of 'Looker-on.' In this relationship between seeing and writing, the Invisible Spy and the Female Spectator make spectatorship the means of subjectivity, achieving the discursive power that authorship confers.

\section{JULIETTE MERRITT \\ McMaster University}

\section{Notes}

1 For a review of the issues underlying this ambivalence, see Benedict.

2 Curiosity's association with excess is the subject of the exemplary story of Nugaculas in Rambler 103. Johnson also understood that curiosity is subjected to an economy of desire and is therefore unsatisfiable: 'the gratification of one desire encourages another, and after all our labours, studies, and enquiries, we are continually at the same distance from the completion of our schemes, have still some wish importunate to be satisfied, and some faculty restless and turbulent for want of employment'(184-86). Because satisfaction is endlessly deferred, curiosity produces restlessness; the gratification of our intellectual impulses does not so much bring the pleasure of satisfaction as ease the pain of ignorance. But if the gratification of curiosity resists closure in Johnson, it is also aligned with the pure pleasure of exercising the mind, of learning for its own sake. 
3 Also see Nicolson, 'New Astronomy' and 'Telescope.' Gilman examines the seventeenth century's interest in optical 'pictures or devices which manipulate the conventions of linear perspective to achieve ingenious effects.... This fascination finds its way into verse not only through the importation of optical imagery but through a deeply-felt concern with the ways we look at the world' (1).

4 According to Nicolson, "The climax of the feminine enthusiasm for the microscope is to be found in The Female Spectator of Eliza Haywood' ('Microscope" 47). For a discussion of Haywood's endeavour to foster women's interest in the microscope see 'Microscope' 47-50.

5 Efforts to develop a theory of female spectatorship are ongoing. For a psychoanalytical contribution, see Doane, 'Film' and 'Masquerade.'

6 As Miller points out, 'Because the gaze is not simply an act of vision, but a site of crisscrossing meanings in which the effects of power relations are boldly (and baldly) deployed, it is not surprising that feminist theorists and writers should take it up as a central scene in their critique of patriarchal authority' (164). For further feminist analyses of the gaze in literature see Newman, 'Getting Fixed' and 'Situation,' and Warhol, 'The Look.' In an eighteenth-century context, see Straub.

7 Swain claims that the focus on the spectator produced a democratization of the observing subject: 'The new emphasis on viewpoint both gave power and took it away - gave it, by placing the viewer at the optimum point of control, and refused it, by making this place open, democratically, to everyone'(7). She does not, however, discuss the possibilities this might hold for the female observer.

8 The desire to discover the 'secret springs' behind human behaviour is also expressed in Le Diable Boiteux, by Alain René Le Sage. First published in 1709, this tale is an early example of the scopic impulse tied to narrative ends. For Cleomas's benefit, Asmodeo 'will lift off the Roofs of the Houses, and notwithstanding the Darkness of the Night, clearly expose to [Cleomas's] view whatever is now under them,' It is not merely an issue of voyeuristic pleasure; spying facilitates a particular kind of knowledge: 'in order to furnish you with a perfect Knowledge of Human Life, it is necessary to explain to you what all those People, which you see, are doing. I will disclose to you the Springs of their Actions, and their most secret Thoughts' (16-17).

9 This is not always the case in Haywood. The spy in Bath Intrigues indulges in voyeuristic pleasure and uses the 'intrigues' he discovers to extort sexual favours. In The Invisible Spy Haywood includes a series of letters which attack, Scriblerian fashion, the Spy's scopic activities.

10 Doody makes a similar point. In Haywood, the heroine is victorious in being perpetual subject. The experience of passion as felt by a female is presented as a full emotional experience, as something that matters ... to a novelist like Mrs. Haywood, the experience of emotion is the only experience that matters' (19).

11 Haywood also employs an invisible observer in one of her scandal chronicles, Memoirs of a Certain Island Adjacent to the Kingdom of Utopia. The narrator is taken up in a cloud by Cupid; together they observe the often sexual activities of humankind. In this Haywood followed most directly Delariviere Manley's The New Atlantis (1709) wherein Astrea (goddess of Justice), Virtue, and Intelligence visit the earth and 'pass unknown and unregarded among the crowd of mortals.' 
12 Despite a reader's understandable curiosity regarding an author's identity, the Invisible Spy is committed to complete anonymity: 'I expect to hear an hundred different names inscribed to the Invisible, - some of which I should, perhaps, be proud of, others as much ashamed to own. - Some will doubtless take me for a philosopher, - others for a fool; - with some I shall pass for a man of pleasure, - with others for a stoic; - some will look upon me as a courtier, - others as a patriot; - but whether I am any one of these, or whether I am even a man or a woman, they will find it, after all their conjectures, as difficult to discover as the longitude' (1-2).

13 And so do the Invisible Spy's readers. 'An Invisible Spy!' writes Scriblerius, 'why it is a character more to be dreaded than an Excise, a Custom-house or a Sheriff's Messenger: - human prudence has taught us to elude the scrutiny of all known examiners; but who can guard against what they do not see?' (8-9)

14 The 'Peeper' embodies what Mulvey calls 'to-be-looked-at-ness,' a term designating woman as not only observed but displayed for male erotic pleasure. 'In their traditional exhibitionist role women are simultaneously looked at and displayed, with their appearance coded for strong visual and erotic impact so that they can be said to connote to-be-looked-at-ness.' For Mulvey, the position of erotic spectacle holds no potential for women to exercise power. See her influential but controversial article, 'Visual Pleasure and Narrative Cinema.'

15 In The Rape of the Lock ('By Force to Ravish, or by Fraud betray' [2.32]), Pope also observes Dante's distinction.

16 For the role the dynamics of the gaze play in Milton's story of Eve's temptation and fall, see Schwartz.

\section{Works Cited}

Addison, Joseph, and Richard Steele. The Spectator. Ed. Donald F. Bond. 5 vols. Oxford: Clarendon $\mathrm{P}, 1965$. All references are to volume 1 of this edition.

Benedict, Barbara M. 'The 'Curious Attitude' in Eighteenth-Century Britain: Observing and Owning.' Eighteenth-Century Life 14 (1990): 59-98.

Bryson, Norman. 'The Gaze in the Expanded Field.' Vision and Visuality. Ed. Hal Foster. Seattle: Bay P, 1988.

Doane, Mary Ann. 'Film and the Masquerade: Theorising the Female Spectator.' Screen 23.3-4 (1982): 74-87.

. 'Masquerade Reconsidered: Further Thoughts on the Female Spectator.' Discourse 11.1 (1988-89): 42-54.

Doody, Margaret Anne. A Natural Passion: A Study of the Novels of Samuel Richardson. Oxford: Clarendon P, 1974.

Foucault, Michel. The Birth of the Clinic. Trans. A. M. Sheridan Smith. New York: Vintage Books, 1975. 
Frye, Northrop. The Secular Scripture. Cambridge MA: Harvard UP, 1976.

Gamman, Lorraine, and Margaret Marchment, eds. The Female Gaze. Seattle: Real Comet P, 1989.

Gilman, Ernest. The Curious Perspective. New Haven and London: Yale UP, 1978.

Haywood, Eliza. Bath Intrigues. 1725. Los Angeles: Augustan Reprint Society, U of California, 1986.

The Female Spectator. 4 vols. London, 1771. All references are to vol. 1 of this edition.

The Invisible Spy. 4 vols. London, 1755. All references are to vol. 1 of this edition.

Love in Excess: or, the Fatal Enquiry. 1719-20. 3rd. ed. reprinted in Secret Histories, Novels, and Poems. 4 vols. London, 1732. All references are to vol. 1 of this edition.

Memoirs of a Certain Island Adjacent to the Kingdon of Utopia. 1725-26.

Johnson, Samuel. The Rambler. 1750-1752. Yale Edition of the Complete Works of Samuel Johnson. Eds. J. Bate and Albrecht B. Strauss. Vols. 4-5. New Haven and London: Yale UP, 1969.

Kaplan, E. Ann. Women and Film. New York: Methuen, 1983.

Le Sage, Alain René. Le Diable Boiteux or the Devil Upon Two Sticks. 1707. Intro. Josephine Grieder. New York: Garland Publishing, 1972.

Manley, Delariviere. The New Atalantis. 1709. Ed. Rosalind Ballaster. London: Penguin Books, 1991.

Miller, Nancy K. Subject to Change: Reading Feminist Writing. New York: Columbia UP, 1988.

Mulvey, Laura. 'Visual Pleasure and Narrative Cinema.' Screen 16.3 (1975): 6-18. Rpt. Mulvey, Visual and Other Pleasures. Bloomington: Indiana UP, 1989.

Newman, Beth. 'Getting Fixed: Feminine Identity and Scopic Crisis in The Turn of the Screw.' Novel 26 (1992): 43-63.

. 'The Situation of the Looker-on: Gender, Narration, and Gaze in Wuthering Heights.' PMLA (1990): 1029-1041.

Nicolson, Marjorie Hope. 'The Microscope and English Imagination.' Smith College Studies in Modern Languages 16 (1935).

. 'The "New Astronomy" and English Literary Imagination.' Studies in Philology 32 (1935): 428-462.

'The Telescope and Imagination.' Modern Philology 33 (1935): 233-260.

Oakleaf, David. 'Introduction.' Eliza Haywood. Love in Excess: or, The Fatal Enquiry. Peterborough: Broadview P, 1994.

Pope, Alexander. The Rape of the Lock. 1714-1717. Poems of Alexander Pope. Ed. John Butt. New Haven: Yale UP, 1963. 217-242.

Schwartz, Regina. 'Rethinking Voyeurism and Patriarchy: The Case of Paradise Lost.' Representations 34 (1991): 85-103. 


\section{Juliette Merritt}

Straub, Kristina. 'Reconstructing the Gaze: Voyeurism in Richardon's Pamela.' Studies in Eighteenth-Century Culture 18 (1988): 419-431.

Swain, Virginia E. 'Lumières et Vision: Reflections on Sight and Seeing in Seventeenthand Eighteenth-Century France.' L'Esprit Createur 28.4 (1988): 5-16.

Warhol, Robyn R. 'The Look, the Body, and the Heroine; A Feminist-Narratological Reading of Persuasion.' Novel 26 (1992): 5-19. 